\title{
Effects of Different Medium on Seed Germination of Spartium junceum L. with Medicinal and Aromatic Importance
}

\author{
Müberra PULATKAN ${ }^{1}$, Nebahat YILDIRIM ${ }^{* 2}$, İbrahim TURNA² \\ ${ }^{1}$ KTÜ, Faculty of Forestry, Department of Landscape Architecture, Trabzon, Turkey \\ ${ }^{2}$ KTÜ, Faculty of Forestry, Department of Forest Engineering, Trabzon, Turkey
}

Received: 04 May 2017 - Revised: 11 September 2017 - Accepted: 12 October 2017

\begin{abstract}
Spartium junceum L., the natural vegetation of Turkey flora, is one of the indicator plants of the Mediterranean climate. Especially in rural landscape, they offer aesthetic wives with floral beauties in dense stains. Functionally, they are effective in planting design in many ecologically distressed areas, such as in sloping areas, highway vegetation, coastal areas affected by sea salt, and so on. They are also preferred for controlling dune areas. In addition to these properties, this species is mainly used as a medicinal and aromatic plant. In particular, the aim of the study were 1) to evaluate the aesthetic, medicinal and aromatic properties of Spartium junceum L. in rural and urban areas in landscape architecture 2) to investigate the effect of different medium on the germination of seeds of Spartium junceum L. As a result of the study, the success of the germination of seeds has been determined: peat 34\%, peat + soil (7: 3) 35,33\% and peat + sand (7:3) 42,67\%. In addition, root length, the number of root and plant length of germinated seedlings were measured. In the statistical analysis results, the best medium of root length and number of roots was determined as peat + sand $(7: 3)$ medium. Peat + sand $(7: 3)$ and peat + soil (7: 3) medium are in the same group in terms of plant height.
\end{abstract}

Keywords: Spartium junceum, planting design, medicinal and aromatic plant, seed germination.

\section{INTRODUCTION}

Nature presents a unique grandeur with its existing plant compositions. Several plants available in natural landscapes with aesthetic qualities are not used in urban landscapes despite the availability of suitable temperature, precipitation and soil conditions. In fact, successful planting applications could be realized with the use of natural plants available in natural plant compositions.

One of the reasons why natural plant species are not used efficiently in plant compositions is that the plant material is not well recognized. Studies conducted to recognize, identify and promote natural vegetation in Turkey are increasing every day. These studies are required to increase the achievements in rural and urban planning, to plant using indigenous plants that could easily adapt to their environment and to contribute to sustainability of the field with postplanting work, to reduce maintenance costs, to increase plant diversity and to convert the natural

${ }^{*}$ Corresponding Author E-mail: nebahat.yildirim@ktu.edu.tr 
resources to economic values. Another reason for the problems related to the use of natural species is the lack of production of these plant materials [1]. This issue is due to the fact that the production methods of natural plant material, breeding techniques and ornamental plant characteristics are not well defined. To clarify these issues, it is necessary to diversify natural flora-based plant material that could be used in urban planting in Turkey, to conduct highway, dune, snow and wind screen, erosion control work, and to increase the variety and amount of inexpensive and easy material that are resistant to harsh ecological conditions and could be used in planting in problem areas such as soil stabilization in tidelands and rural areas [2-6].

One of the most significant tasks of landscape architecture and ornamental plants disciplines is to determine the plant material suitable for use in planning and planting studies. Lack of knowledge on ecological, phenological, dendrological, aesthetic and functional properties of plant material and thus improper plant use affect the application success rate and cause problems in the expected benefits of the applications [4, 7].

Spartium junceum L., the only natural species in the Spartium L. genus of the Leguminosae family, is the Western Mediterranean plant. It is indigenous to Northwestern and Southern Anatolia in Turkey. It grows in coastlines, arid, rocky and calcareous areas. Due to its strong root system, it could survive on steep slopes. It grows in sunny, destitute and welldrained soil $[4,8,9]$. It is a green, approximately $3 \mathrm{~m}$ tall, delicate and dispersed evergreen bush. A neat form can be created with proper pruning. The leaves are 1-2 cm long and blueishgreen. The flowers are bright yellow with a beautiful fragrance. They start to blossom from May and cover the entire plant intensely. Fruits are elongated and bean-like, seeds inside are small and hard-shelled, dark brown and sometimes black when ripe $[10,11]$. It is among the species that can be used as a soil retainer in erosion control thanks to its strong root system development. It could also be used as cut flowers [12-14].

The present study aimed to assess the aesthetic, medicinal and aromatic properties of Spartium junceum L. in landscape architecture in rural and urban areas and to determine the effects of different medium on Spartium junceum L. seed germination.

\section{MATERIAL and METHODS}

The seed capsule material used in the study was collected at sea level from the Trabzon coastline in November. Capsules were dried at ambient temperature and in humid environment. Dried capsules were manually broken and seeds were removed. The extracted seeds were stored at $2-4{ }^{\circ} \mathrm{C}$ until sowing. 1000 seed weight was calculated according to ISTA [15] before seeds were sowed.

Germination experiments for Spartium junceum L. seeds were conducted at $25 \pm 2{ }^{\circ} \mathrm{C}$ temperature and $70 \pm 2 \%$ humidity environment at the research and application greenhouse in Faculty of Forestry, Karadeniz Technical University. Peat, peat+soil (7:3) and peat+sand (7:3) media were used as germination medium. Line sowing method was used in the sowing of the seeds and sowing was conducted based on the random trial design. In the prepared crates, lines were opened to the depth of 2-3 times of the thickness of the seed with the line opening bar. Seeds were sowed with 3x100 sampling in March.

The irrigation procedure was performed with sprinkling method and equal amounts of water were carefully provided for each crate. Furthermore, weeds were also removed from the medium during the study. At the end of the study, the seed germination status was evaluated. In addition, root lengths, the number of root and plant size of the germinated seedlings were measured. 
In the assessment of Spartium junceum L. based on landscaping, both observations and literature were utilized. Furthermore, its medicinal and aromatic significance was based on the findings in previous studies.

\section{FINDINGS}

\subsection{Evaluation of Spartium junceum L. on Landscape Architecture}

With respect to Landscape Architecture, Spartium junceum L. is a valuable plant for planting design with its form and floral qualities. This species could be utilized as a single plant or in groups as an accent plant with its interesting yellow bright flowers (Figure 1a, 1b). In addition to their aesthetic qualities, the plant is effective in several functional areas with ecological problems. Due to its strong root structure, it develops well in sloping areas and provides land control while at the same time forming dense stains with its flower quality (Figure 1c). Highways constitute a threat for several plants. Spartium junceum L. grows naturally on highway edges and continues to develop under difficult conditions. In highway landscaping, they produce stimulating effects with effective flowering (Figure 1d). It is also effective when used in planting designs under seawater-sprinkled coastal margins due to its resistance to salty soils.
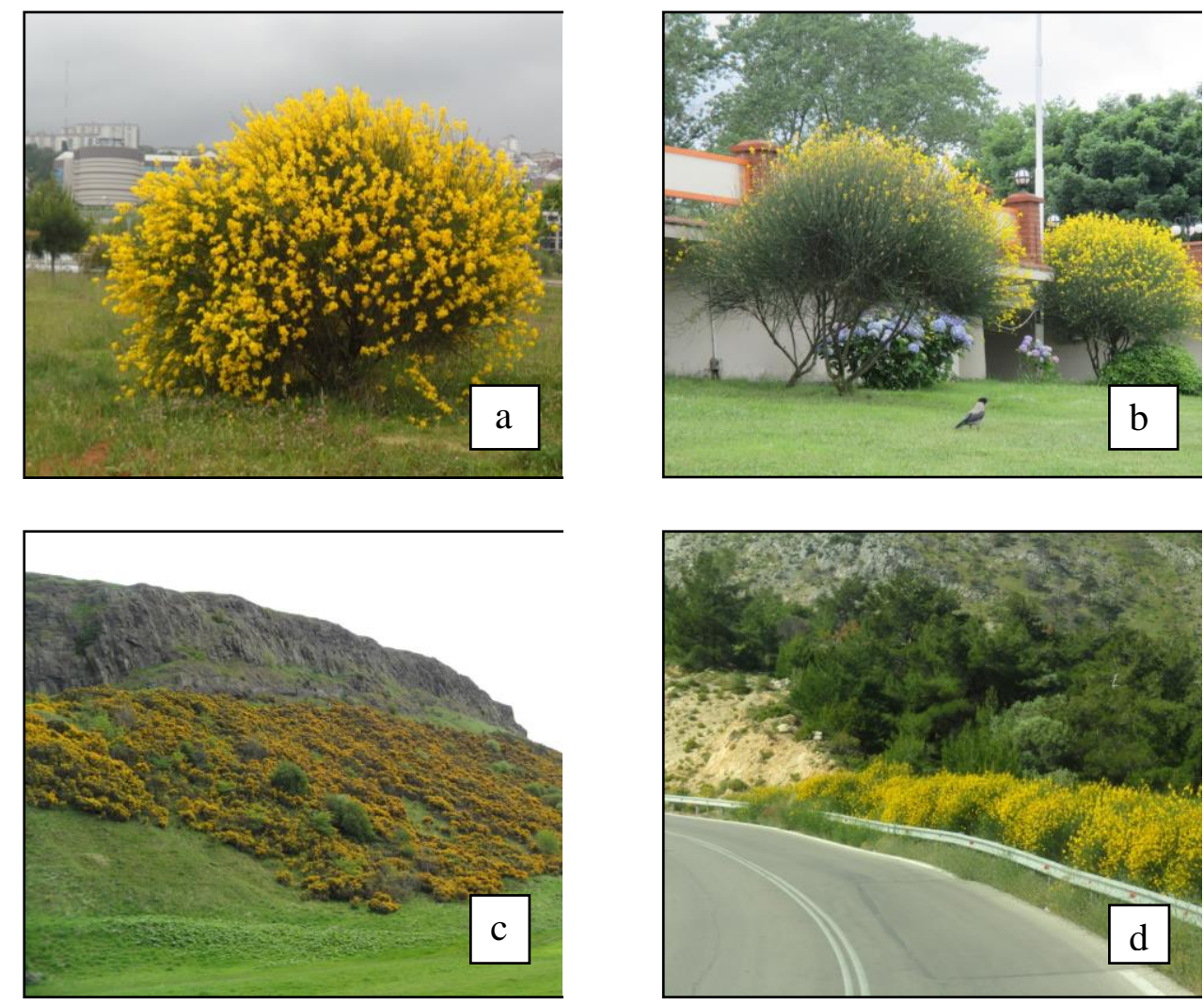

Figure 1. Use of Spartium junceum L. in Landscape Architecture

\subsection{Medicinal and Aromatic Significance of Spartium junceum L.}

It was determined that a saponin strain that Spartium junceum L. flowers contain causes ulcer [16]. Dried flowers are used as an infusion (1\%) due to mild narcotic and diuretic action [17]. It is included in the medicinal plant class due to the stimulatory effects of the alkaloids it contains and isolated from its body on the muscle system $[18,19]$. It helps pass kidney and gall bladder stones. It treats bladder diseases. It has benefits in rheumatism. It eliminates constipation. It is also used in heart diseases. The whole plant, especially flowers and seeds, is 
toxic. Poisoning can be observed in children who eat the plant due to its sweet taste and in animals that eat the mature fruits. Toxicity manifests itself with distress, headache and diarrhea [20]. It contains luteolin that stains the wool in orange-yellow, olive green and bright yellow colors [21].

\subsection{Findings on Seed Cultivation of Spartium junceum $\mathrm{L}$.}

\subsubsection{Seed Weight}

Randomly selected $8 \times 100$ seeds were weighed on a precision scale and 1000 seed weight was determined [15]. Measurements demonstrated that the weight of 1000 seeds were 15, 26 gr.

\subsubsection{Germination Rates}

The germination status of Spartium junceum L. seeds cultivated in different media were observed at 1-week intervals from the first day of germination (Table 1). Germination rates obtained at the end of the study were determined for peat $(34 \%)$, peat+soil $(35,33 \%)$ and peat+sand $(42,67 \%)$ media. The best germination was observed in peat+sand medium and the lowest germination was observed in peat medium (Figure 2).

Table 1. 3rd and 7th week germination status of Spartium junceum L. seeds

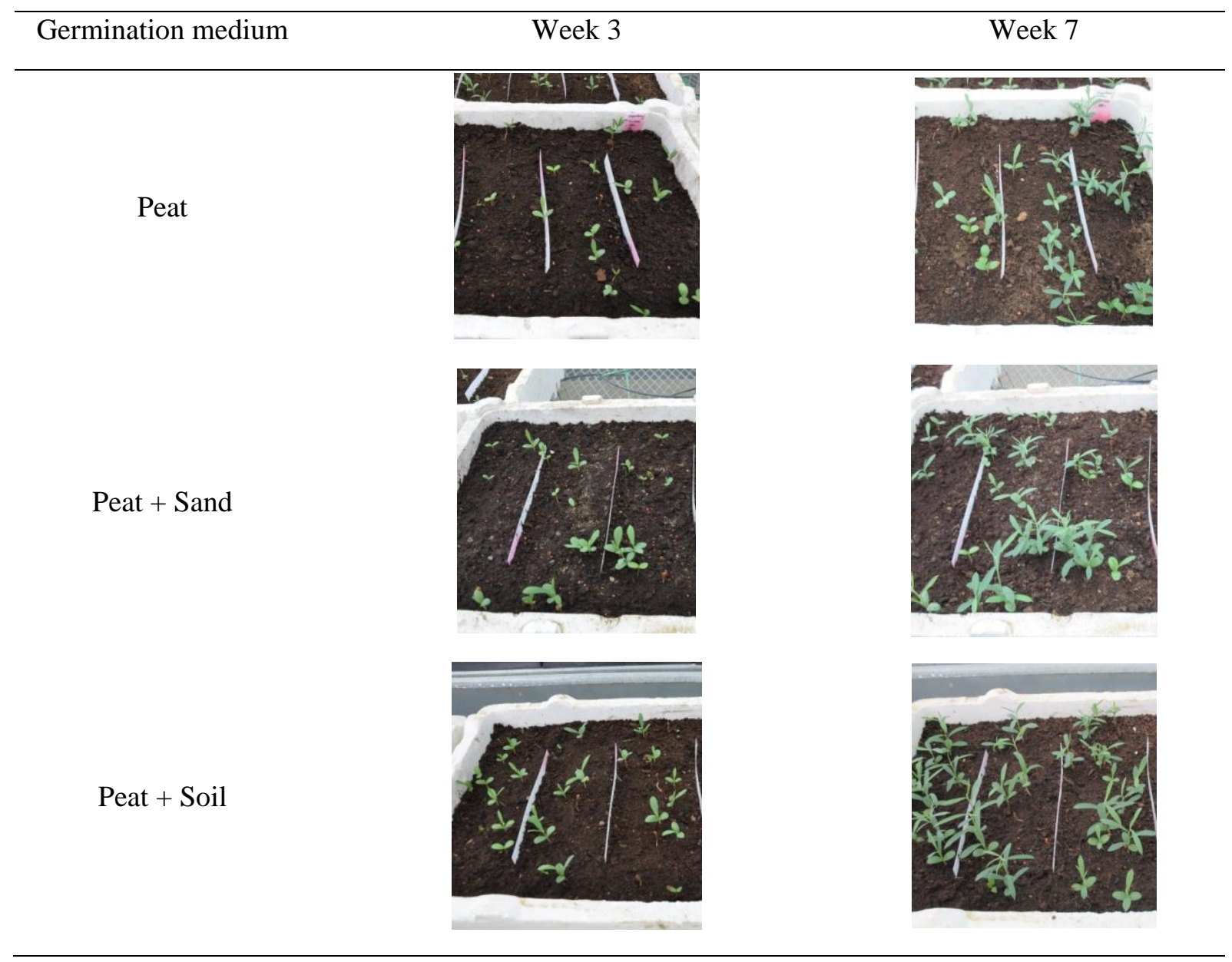




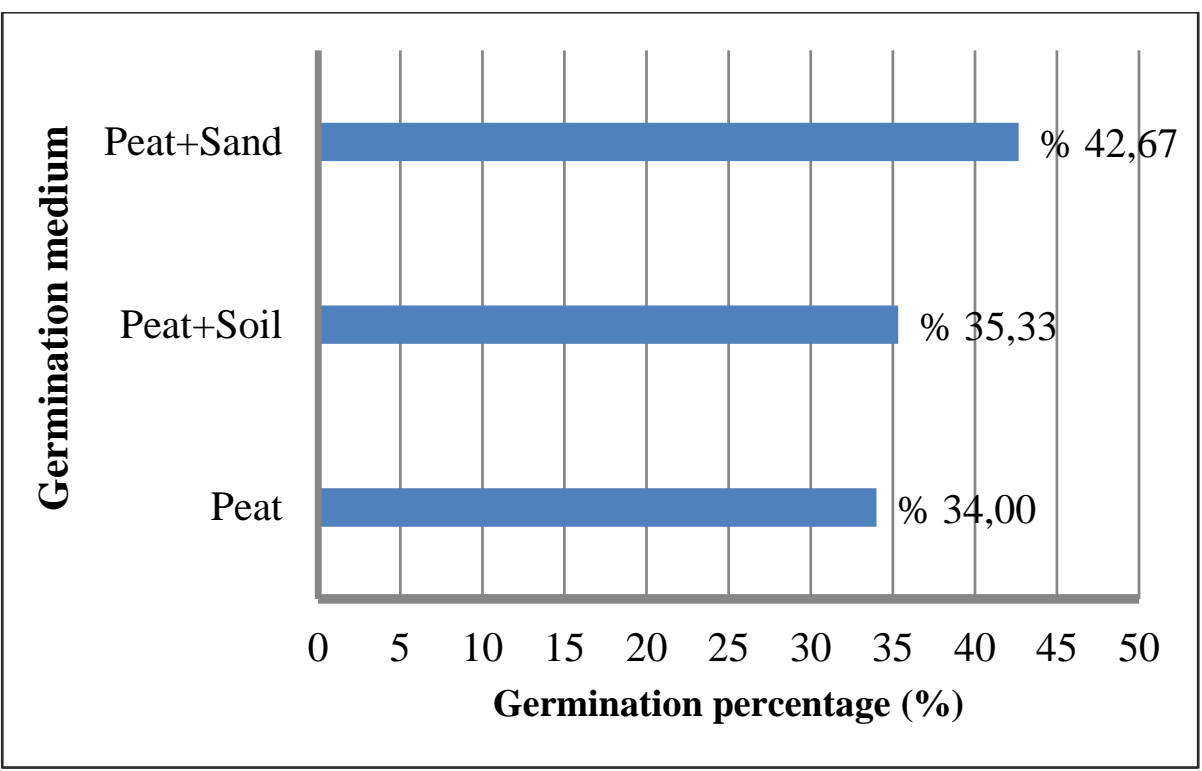

Figure 2. Germination success of Spartium junceum L. seeds in different media.

\subsubsection{Root and Plant Sizes}

Once the seed germination status was determined, the plant and root length of the seedlings were measured. Differences between the measured plant and root length data based on the medium were determined by analysis of variance. The Duncan test was also applied to group the data based on the media. The results of the conducted tests are presented in Table 2.

Table 2. Analysis of variance and Duncan test for Spartium junceum L. seedlings according to plant and root length in different germination media

\begin{tabular}{|c|c|c|c|c|}
\hline & Media & $\begin{array}{c}\text { Mean/ Standard } \\
\text { deviation }\end{array}$ & $\mathrm{F}$ & $\mathrm{P}$ \\
\hline & Peat + Soil & $14,06 \pm 12,60 \mathrm{a}$ & & \\
\hline $\begin{array}{l}\text { Plant length } \\
(\mathrm{cm})\end{array}$ & $\begin{array}{c}\text { Peat }+ \text { Sand } \\
\text { Peat }\end{array}$ & $\begin{aligned} 13,79 & \pm 17,05 \mathrm{a} \\
9,62 & \pm 5,90 \mathrm{~b}\end{aligned}$ & 4,073 &, $018^{*}$ \\
\hline $\begin{array}{l}\text { Root length } \\
(\mathrm{cm})\end{array}$ & $\begin{array}{c}\text { Peat }+ \text { Sand } \\
\text { Peat } \\
\text { Peat }+ \text { Soil }\end{array}$ & $\begin{array}{l}11,65 \pm 5,52 \mathrm{a} \\
9,08 \pm 3,13 \mathrm{~b} \\
9,07 \pm 5,59 \mathrm{~b}\end{array}$ & 12,368 &, $000^{*}$ \\
\hline
\end{tabular}

[ $\mathrm{P}<0,05$ significant $]$

The results displayed in Table 2 demonstrated that germination media affected both plant and root length. The most successful media in terms of plant length were observed peat+soil and peat+sand media. It was determined that the least successful medium was the peat medium. In terms of root length, the highest value was determined in peat+sand medium, while the lowest value was observed in peat and peat + soil media.

\subsubsection{Root and Plant Sizes}

Once the seed germination status was determined, the plant and root length of the seedlings were measured. Differences between the measured plant and root length data based on the medium were determined by analysis of variance. The Duncan test was also applied to group the data based on the media. The results of the conducted tests are presented in Table 2 . 


\subsubsection{The Number of Root}

When the number of root of the seedlings was determined, 9 and higher root number values were considered as $\mathrm{H}$ (High), 5-9 were considered as $\mathrm{M}$ (Medium) and 1-4 were considered as L (Low). Percentage values related to whether the media were effective on the root number are presented in Table 3.

Table 3. The number of root rates based on germination media

\begin{tabular}{lccc}
\hline \multirow{2}{*}{ Medium } & \multicolumn{3}{c}{ The number of root (\%) } \\
& $\mathrm{H}$ & $\mathrm{M}$ & $\mathrm{L}$ \\
\hline Peat & 29,41 & 31,37 & 39,22 \\
Peat + Soil & 24,53 & 35,85 & 38,68 \\
Peat + Sand & 42,97 & 28,13 & 28,91 \\
\hline
\end{tabular}

Based on the results, the highest root number $(\mathrm{H})$ percentage was found in seedlings grown in peat + sand medium. The lowest root number (L) was detected in seedlings in the peat medium. Thus, the lowest root number was observed in the peat medium.

\section{RESULTS AND DISCUSSION}

Landscape design allows us to utilize the environment the best way possible. Plant design helps us to preserve and renew a sustainable relationship between the changing environment and individuals. The three interdependent reasons for plant design are use, ecology and aesthetics [22]. Providing aesthetic and functional value in plant design is only possible if it could resolve functional problems as well as providing natural aesthetics such as the form of plants, foliage characteristics, flower beauty, etc. as well as natural beauty, many problem solutions can be also functional. It is considered that Spartium junceum L. would increase the success of planting designs in rural and urban landscapes when it is evaluated with its functional features due to its ecological characteristics as well as its aesthetic properties. Furthermore, since it is an indigenous species, it would reduce the maintenance costs by providing a continuous planting design. Because of these properties, the need to encourage the cultivation of Spartium junceum L. plant seed production was emphasized and seed cultivation was tested in different media in the present study.

Conducted analyzes demonstrated that 1000 seed weight was 15,26 gr. In the study conducted by Gültekin [23], Spartium junceum L. 1000 seed weight was reported as 10-16 gr (13 gr). When the seed germination rates were examined, it was determined that seed germination rate in peat medium was $34 \%$, in peat + soil (7: 3) medium it was $35,33 \%$ and in peat + sand $(7: 3)$ medium it was $42,67 \%$. Furthermore, root lengths, the number of root and plant size of germinated seedlings were measured. Statistical analysis results showed that the best medium for root length and the number of root was the peat + sand (7:3) medium. For plant size, peat + soil and peat + sand media were in the same group. Erken et al. [24] determined the germination rates at $10{ }^{\circ} \mathrm{C}$ and $20{ }^{\circ} \mathrm{C}$ controlled conditions in petri dishes in their study, and after 60 days, they obtained $27.67 \%$ at $10^{\circ} \mathrm{C}$ and $39.27 \%$ at $20^{\circ} \mathrm{C}$ germination

\section{Acknowledgement}

This study was supported by Karadeniz Technical University Scientific Research Project Department with grant no: 9733. Also, the present study was published as summary text on abstract book in 1st International Congress on Medicinal and Aromatic Plants.

\section{Conflict of Interests}

Authors declare that there is no conflict of interests. 


\section{REFERENCES}

[1]. Erken, K. (2011). Spartium junceum L., Chamaecytisus hirsutus (L.) Link. ve Genista lydia Boiss var. lydia Taksonlarının Çoğaltım Yöntemleri ve Süs Bitkisi Özelliklerinin Belirlenmesi. Doktora tezi, Ege Üniversitesi, Fen Bilimleri Enstitüsü, İzmir.

[2]. Köse, H. (1998). Ege Bölgesinde Doğal Olarak Yetişen Bazı Çalı Tohumlarının Çimlendirme Yöntemleri Üzerinde Araştırmalar. I. Ulusal Süs Bitkileri Kongresi, 6-9 Ekim, 255-264s. Yalova, Türkiye.

[3]. Sarıbaş, M. (1998). Batı Karadeniz Bölgesinde Doğal Olarak Yetişen Odunsu Süs Bitkileri. I. Ulusal Süs Bitkileri Kongresi, 6-9 Ekim, 44-50s, Yalova, Türkiye.

[4]. Y1lmaz, R. (1999). Otoyol Peyzaj Planlamasında Kullanılmaya Uygun Bazı Doğal Otsu ve Odunsu Bitkilerin Otoyol ve Fidanlık Koşullarında Yetiştirilme Olanakları Üzerinde Araştırmalar. Doktora Tezi, Ege Üniversitesi Peyzaj Mimarlı̆̆ Anabilim Dalı, İzmir.

[5]. Barış, M.E. (2002). Yeşil Alan Uygulamalarında Doğal Bitki Örtüsünden Yeterince Faydalanıyor muyuz? II. Ulusal Süs Bitkileri Kongresi, 22-24 Ekim, 91-95s. Antalya, Türkiye.

[6]. Yazgan, M. E., Korkut, A. B., Barış E., Erkal, S.,Yılmaz, R., Erken, K., Gürsan, K. \& Özyavuz M. (2005). Süs Bitkileri Üretiminde Gelişmeler. Türkiye Ziraat Mühendisliği VI. Teknik Kongresi, 3-7 Ocak 2005 Cilt I, 589-607s. Ankara, Türkiye.

[7]. Koç, N. (1977). Orta Anadolu Bölgesinin Kurağa Dayanıklı Yer Örtücü Bazı Önemli Doğal Çalı ve Çok Yıllık Otsu Bitkilerinin Peyzaj Mimarisi Yönünden Değerlendirilmesi Üzerine Bir Araştırma. Ankara: TÜBİTAK Tarım ve Ormancılık Grubu, Kurak Bölge Araştırmaları Proje No:9.

[8]. Bayraktar, A., Köseoğlu, M. \& Güney, A. (1980). Ege Bölgesinde Doğal Olarak Yetişen Odunsu Bitkilerin Ekolojik Özelliklerinin Saptanması ve Kültüre Alınması Üzerinde Araştırmalar. İzmir: TÜBİTAK TOAG Proje No: 327.

[9]. Anonim (2003). A-Z Encyclopedia of Garden Plants, The Royal Horticultural Society, Editör-In Chief Chirostopher Brickell Volume I and II, ISBN: 0-7513-3738-2. London: Dorling Kindersley Limited.

[10]. Pamay, B. (1993). Bitki Materyali II, Odunsu Kökenler-Çiçekli Çalılar, Sarmaşıklar, Kaktüsler ve Sukkulent Bitkiler, Saz ve Kamışlar. Orhan Ofset, İstanbul.

[11]. Warren, W. (2004). Botanica, Könemann. Tandem Verlag GmbH, Italy.

[12]. Akalın, Ş. (1952). Büyük bitkiler kılavuzu. Ankara Basım ve Cilt Evi, 752s Ankara.

[13]. Kayacık, H. (1966). Orman ve Park Ağaçlarının Özel Sistematiği, III. Cilt Angiospermae (Kapalı Tohumlular). İstanbul: İstanbul Üniversitesi Orman Fakültesi Yayınları Orman Fak. No:1189/106291s.

[14]. Davis, P. H. (1965-85). Flora of Turkey and the East Aegean Islands. Vol. III. Edinburgh: Edinburgh University Press.

[15]. ISTA, International Seed Testing Association (1996). International Rules for Seed Testing. Rules Seed Sci. Technol. 24 (Supplement), 241-335.

[16]. Yeşilada, E. \& Takaishi Y. (1999). A Saponin with anti-Ulcerogenic effect from the flowers of Spartium junceum. Phytochemistry, 51(7), 903-908.

[17]. Baytop, T. (1999). Türkiye'de bitkilerle tedavi. İstanbul: Nobel Tıb Kitabevi.

[18]. Cave, A. (1995). Pharmacognosy, Phytochemistry, Medicinal Plants. Paris: Lavoiser Publishing Inc. 
[19]. Bezic, N. A. D. A., Dunkic, V. A. L. E. R. I. J. A., \& Radonic, A. (2003). Anatomical and chemical adaptation of Spartium junceum L. in arid habitat. Acta Biologica Cracoviensia Series Botanica, 45(2), 43-47.

[20]. Anonim (2007). Boya Bitkileri. http://www.tar-gel.com.

[21]. Karadağ, R. (2007). Doğal Boyamacılık. Ankara: T.C. Kültür ve Turizm Bakanlığı, Döner Sermaye İşletmesi Merkez Müdürlüğü.

[22]. Robinson, N. (1992). The Planting Design Handbook. England: Gower Publishing Company Limited.

[23]. Gültekin, H.C. (2010). Kapalı Tohumlu (Angiospermae) Ağaç ve Çalıların Eşey Özellikleri. El Kitabı, Ankara: T.C. Çevre ve Orman Bakanlığı Ağaçlandırma ve Erozyon Kontrolü Genel Müdürlüğü.

[24]. Erken, K. \& Özzambak, M. E. (2012). Spartium junceum L.'de Tohum Çimlenmesi ve Süs Bitkisi Özelliklerinin Belirlenmesi. Bahçe, 41 (1), 9 - 23. 